\title{
Experimental embryology of mammals at the Jastrzebiec Institute of Genetics and Animal Breeding
}

\author{
JOLANTA KARASIEWICZ* and JACEK ANDRZEJ MODLINSKI \\ Department of Experimental Embryology, Institute of Genetics and Animal Breeding, Polish Academy of Sciences, Poland
}

\begin{abstract}
Our Department of Experimental Embryology originated from The Laboratory of Embryo Biotechnology, which was organized and directed by Dr. Maria Czlonkowska until her premature death in 1991. Proving successful international transfer of frozen equine embryos and generation of an embryonic sheep-goat chimaera surviving ten years were outstanding achievements of her term. In the 1990s, we produced advanced fetuses of mice after reconstructing enucleated oocytes with embryonic stem (ES) cells, as well as mice originating entirely from ES cells by substitution of the inner cell mass with ES cells. Attempts at obtaining ES cells in sheep resulted in the establishment of embryo-derived epithelioid cell lines from Polish Heatherhead and Polish Merino breeds, producing overt chimaeras upon blastocyst injection. Successful recloning was achieved from 8-cell rabbit embryos, and healthy animals were born from the third generation of cloned embryos. Recently mice were born after transfer of 8-cell embryonic nuclei into selectively enucleated zygotes, and mouse blastocysts were produced from selectively enucleated germinal vesicle oocytes surrounded by follicular cells, upon their reconstruction with 2-cell nuclei and subsequent activation. Embryonic-somatic chimaeras were born after transfer of foetal fibroblasts into 8-cell embryos (mouse) and into morulae and blastocysts (sheep). We also regularly perform the following applications: in vitro production of bovine embryos from slaughterhouse oocytes or those recovered by ovum pick up; cryopreservation of oocytes and embryos (freezing: mouse, rabbit, sheep, goat; vitrification: rabbit, cow); and banking of somatic cells from endangered wild mammalian species (mainly Cervidae).
\end{abstract}

KEY WORDS: mouse, sheep, cloning, chimaera, ES cell, cryopreservation

\section{History}

The Department of Experimental Embryology originated from The Laboratory of Embryo Biotechnology, which was organized and directed by Dr Maria Czlonkowska, D.Sc. (Fig. 1), until her premature death in 1991.

The first and one of the most prominent achievements of $\mathrm{Dr}$ Czlonkowska and her team was a successful cryoconservation of equine embryos. Out of the first four foals, which were born in early eighties from frozen embryos, one was obtained by $\mathrm{Dr}$ Czlonkowska in collaboration with DrW.R. Allen (Czlonkowska et al., 1985). After transporting frozen embryos from Poland to United Kingdom (Cambridge) and transferring them to recipient mares, Konik Polski's foal, named Winston (Fig. 2), was delivered (Boyle et al., 1985), proving successful international transfer of frozen equine embryos.

Generation of inter-species chimaeras by aggregation of 8- cell goat and sheep embryos was another achievement of this laboratory. The obtained chimaera (Czlonkowska et al., 1988; Jaszczak et al., 1991), a male named Hobgoblin (Fig. 3), survived ten years and served as the source of information about changing contributions from both embryo-derived components to the tissues of the chimaera throughout his lifespan (Jaszczak et al., 1999).

The birth of lambs following in vitromaturation, fertilization and subsequent co-culture of embryos with sheep oviductal epithelial cells (Czlonkowska et al., 1991), as well as the production of sheep monozygotic twins after bisection of fresh or frozen embryos at the blastocyst stage, complete the list of scientific achievements of The Laboratory of Embryo Biotechnology.

Abbreviations used in this paper: ES, embryonic stem (cell); GV, germinal vesicle; ICM, inner cell mass.

\footnotetext{
*Address correspondence to: Dr. Jolanta Karasiewicz. Department of Experimental Embryology, Institute of Genetics and Animal Breeding, Jastrzebiec, 05552 Wolka Kosowska, Poland. Fax: +48-22-756-1417. e-mail: J.Karasiewicz@ighz.pl
} 


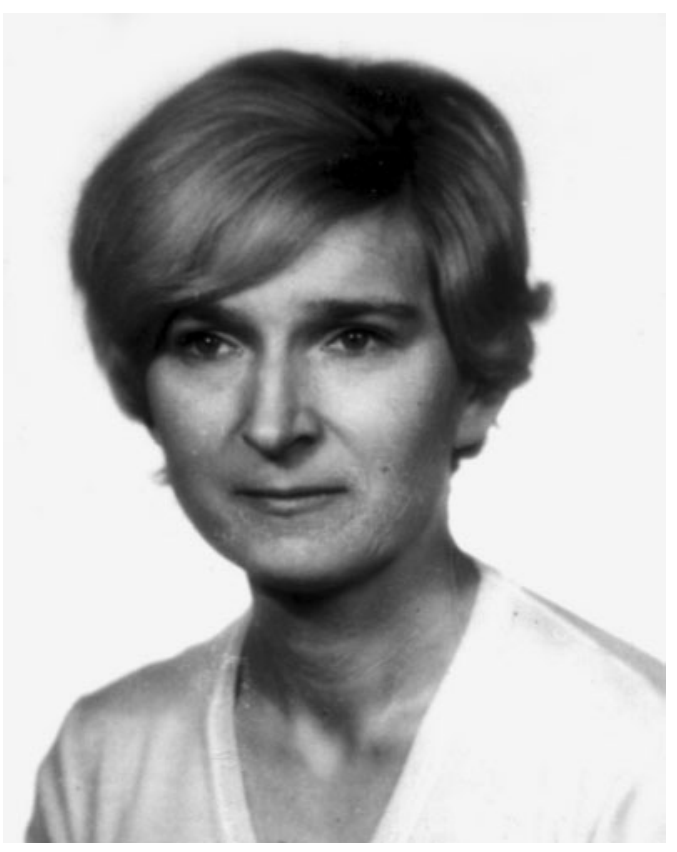

Fig. 1. Dr Maria Czlonkowska, D.Sc. (1944 -1991), founder of The Department of Experimental Embryology.

In autumn 1990 Dr Jolanta Karasiewicz - Ph.D alumnus of Professor A. K. Tarkowski (Department of Embryology, Institute of Zoology, Warsaw University) - joined The Laboratory of Embryo Biotechnology, with the aim of obtaining embryonic stem cells from sheep, and the next year Dr Jacek A. Modlinski - of the same scientific background - came from Edison Biotechnology Center Ohio University (USA), where he had worked as visiting professor, to take the position of the Head of the Laboratory. A new building was ready soon, harbouring - between the others -
The Department of Experimental Embryology. The scientific staff of Dr. Czlonkowska's laboratory (Drs Andrzej Guszkiewicz and Krzysztof Papis as well as Maciej Korwin-Kossakowski, M.Sc. and Grzegorz Stefanski, M.Sc) together with the whole technical team of the Laboratory, became the core of the new Department. In 1996, Dr Anna M. Duszewska - Ph.D alumnus of Professor Zofia Bielanska-Osuchowska (Warsaw Agricultural University) joined the group with the aim of producing bovine embryos in vitro.

Studies currently conducted at The Department of Experimental Embryology are the continuation of those initiated by $\mathrm{Dr}$ Czlonkowska, and those conducted by Drs Karasiewicz and Modlinski at Warsaw University. The current program of the Department has been extended to studies of laboratory animals (mouse, rabbit) and to the new areas of experimental embryology and biotechnology such as embryonic and somatic cloning (mouse, rabbit and sheep), obtaining embryo-derived cell cultures in livestock species, generation of embryonic-somatic chimaeras (mouse, sheep) and production of transgenic animals (pig, cattle).

\section{Scientific program}

In the 1990s, we produced advanced fetuses of mice after reconstructing enucleated oocytes with embryonic stem (ES) cells, as well as mice originating entirely from ES cells. The latter mice were produced using an original method in which ES cells were introduced into blastocysts which were earlier depleted of their inner cell masses (ICM) by microsurgical removal (Fig. 4) (Modlinski, 1995; Modlinski et al., 1996) or they were introduced into ICM-free trophoblastic vesicles obtained after mild heat shock treatment of early embryos (Modlinski etal., 2003; Modlinski et al., 2004).

Attempts at obtaining ES cells in sheep were undertaken by Karasiewicz et al. (1996), resulting in establishing of ectodermal embryo-derived epithelioid cell lines from Polish Heatherhead
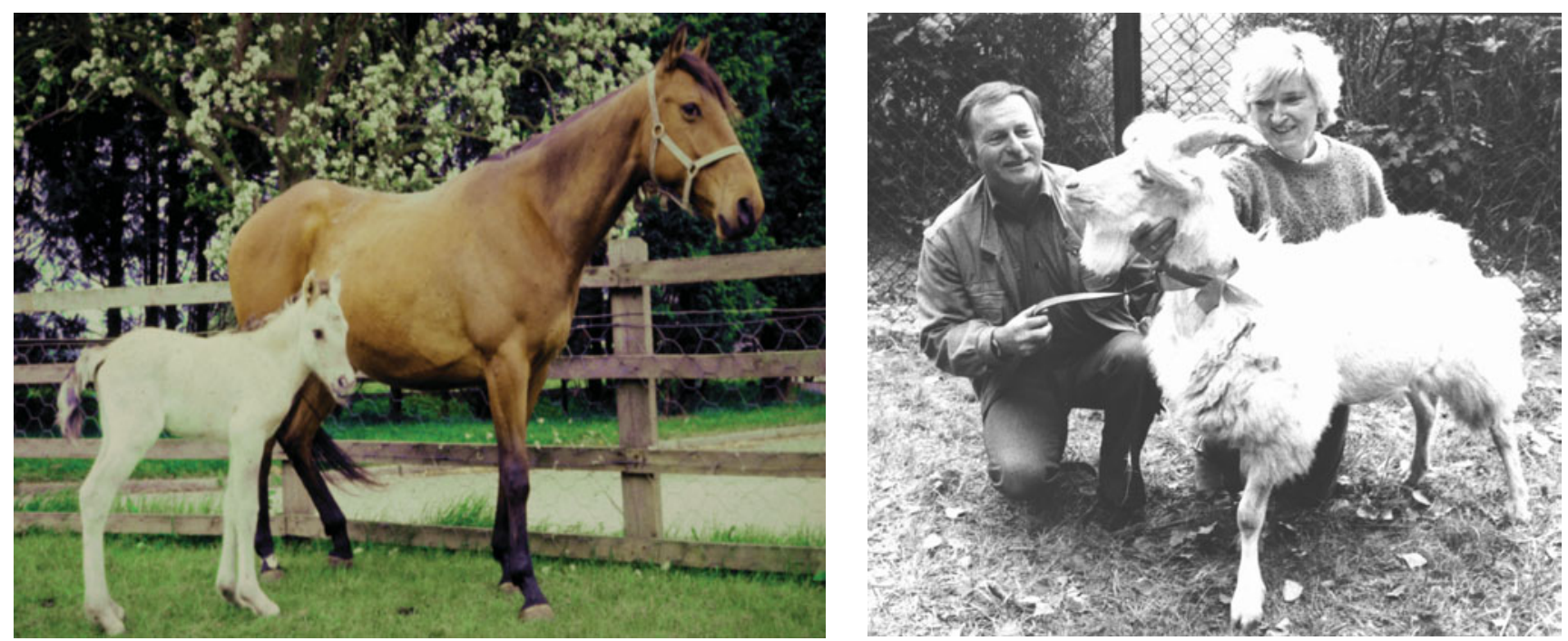

Fig. 2 (Left). Winston, the first foal of Polish Konik, derived from an embryo which was frozen in Poland and then was transported to the UK to be transferred there. Here, the foal is shown with its foster mother. Courtesy of Professor Marian Tischner.

Fig. 3 (Right). An experimentally produced goat-sheep embryonic chimaera named Hobgoblin. The animal is accompanied by Drs. Maria Czlonkowska and Andrzej Guszkiewicz. 

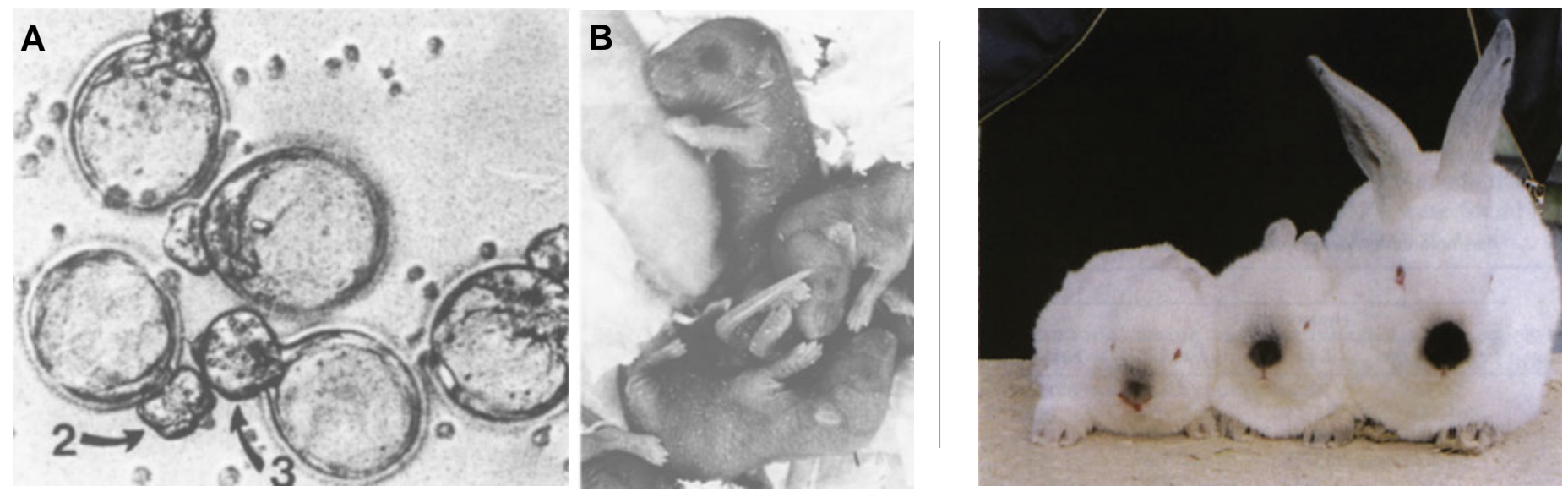

Fig. 4 (Left). Obtaining embryonic stem(ES) cell-derived mice by inner cell mass (ICM) substitution (A) ICMs are expelled from blastocysts (arrows), to be substituted by ES cells. (B) A mouse (the big one) totally derived from ES cells (Anim. Reprod. Sci. 42: 437-446, 1996, with permission).

Fig. 5 (Right). Rabbits born from the third generation of cloned embryos (the big rabbit is older than the smaller ones). Biol. Reprod. 63: 677-682 (2000), with permission.

and Polish Merino breeds. The former cells were used - via blastocyst injection - for the generation of sheep overt chimaeras (Modlinski et al., 1996).

Successful re-cloning was achieved by obtaining twenty seven blastocysts after the third round of serially cloning 8-cell embryos, and healthy rabbits were born from the third generation of 8-cell embryos (Fig. 5) (Piotrowska et al., 2000). Special attention was paid to mouse cloning. We have tried to clone mice using recipient cells, as an alternative to enucleated MII oocytes, such as telophase zygotes (Plusa et al., 2005). Recently mice were born after transfer of embryonic nuclei into enucleated zygotes (Greda et al., 2006). The zygotes were enucleated by an original method of selective enucleation developed from the zygotes' enucleation technique described previously by Modlinski (1975). In this method only the pronuclear envelope with the attached chromatin was removed leaving the liquid pronuclear contents and nucleoli in the cytoplasm (Fig. 6). The origin of cloned mice was confirmed by coat color and GPI analysis. The blastocysts were obtained after transfer of ES cell nuclei into selectively enucleated zygotes (Greda, Ph.D. Thesis). Also, we were able to produce mouse
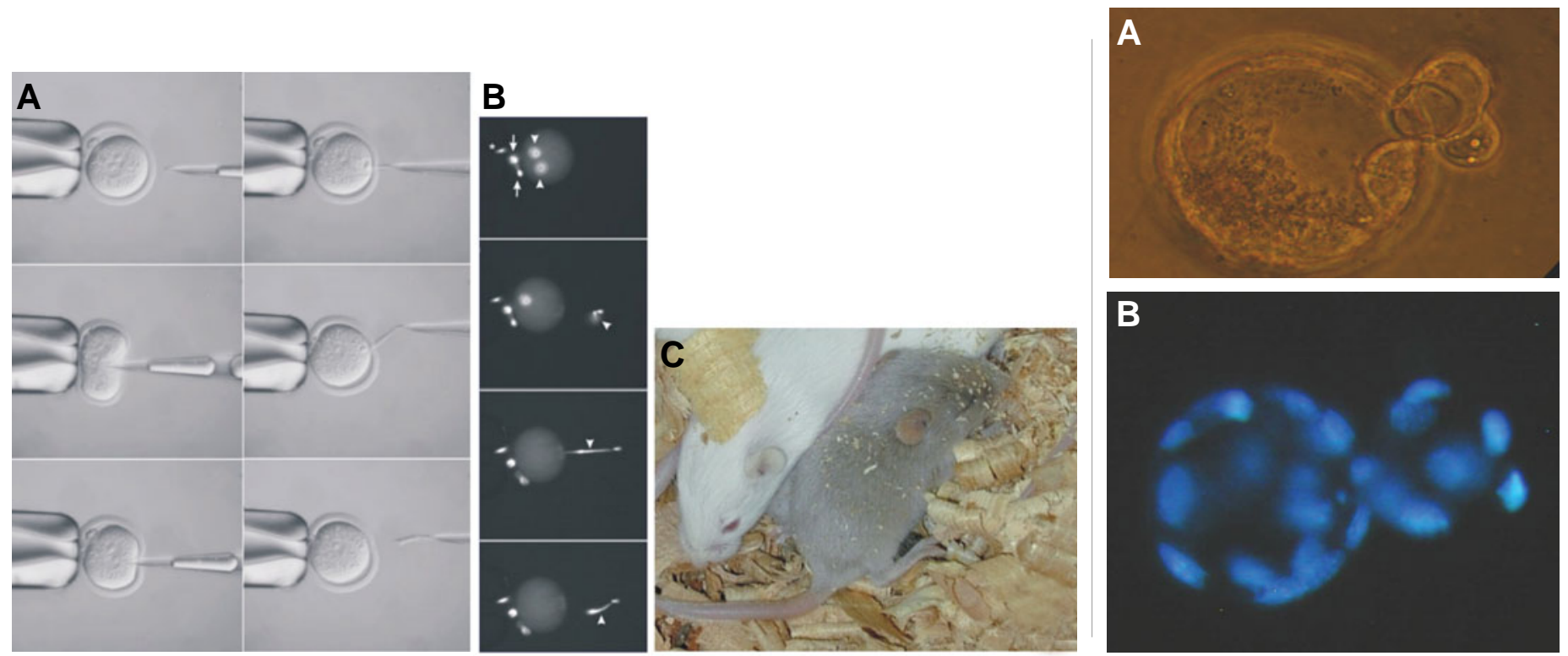

Fig. 6 (Left). Cloning mice from zygotes. (A) Selective enucleation of a mouse zygote. (B) The same procedure as in (A), but Hoechst stained chromatin is shown to be removed from the zygote. (C) A mouse born after transfer of a nucleus from a pigmented mouse strain to a selectively enucleated zygote from a mouse of an unpigmented strain. Reproduction 132: 741-748 (2006), with permission.

Fig. 7 (Right). Cloning mice from germinal vesicle (GV) oocytes. (A) A blastocyst developed after GV oocytes (enclosed within follicular cells) were selectively enucleated, reconstructed with a 2-cell stage blastomere, and then matured, activated and cultured in vitro, phase contrast. (B) Similar blastocyst after Hoechst staining, seen under UV light. Cell nuclei are visible. (A.A. Mohammed, PhD thesis, 2006). 

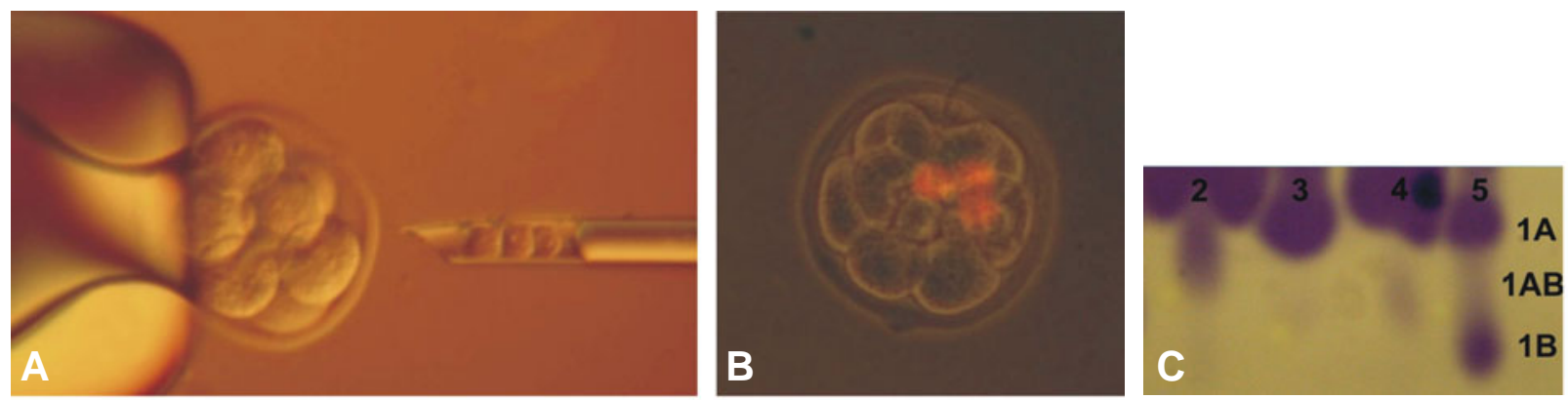

Fig. 8. Obtaining embryonic-somatic chimaeras. (A) Foetal fibroblasts being introduced into a mouse 8-cell embryo. (B) Fibroblasts (stained red) visible in the embryo. (C) Electrophoretic detection of GPI-1A1B hybrid isozyme in brain tissues of born mice (lane 2, a fertile male; 3, an infertile female; 4, a fertile female), indicating fusion of fibroblast progeny with recipient cells. (GPI-1A, recipient isozyme; GPI-1B, donor isozyme; GPI-1AB, hybrid isozyme).

blastocysts from selectively enucleated germinal vesicle (GV) oocytes surrounded by follicular cells, upon their reconstruction with 2-cell nuclei and subsequent activation (Fig. 7) (Mohammed et al., 2008). When tested as the recipients of embryonic nuclei, classically enucleated GV oocytes have proved capable of remodeling blastomere nuclei, so that they followed the path of meiotic cell cycle (Grabarek et al., 2004).

The influence of early embryonic environment on somatic cells is another goal of our team and the embryonic-somatic chimaeras are the model used. Chimaeric mice and sheep were born after transfer of foetal fibroblasts into 8-cell embryos (mouse) and into morulae and blastocysts (sheep). In the mouse, it was shown by GPI analysis that, starting from the day 11-12 of development, the introduced somatic cells fuse with the host cells, and can persist - as hybrid cells - in tissues derived from all three germ layers (Fig. 8) (Piliszek etal., 2007). Also, in sheep, the presence of progeny of the introduced somatic cells was found as was shown by RAPD analysis - in several tissues derived from three germ layers (Karasiewicz et al., 2008, pp. 315-322 this issue).

Cryopreservation of oocytes and embryos (freezing: mouse, rabbit, sheep, goat; vitrification: rabbit, cattle) was also successfully performed in our laboratory (Papis et al., 1999). Fine modification of vitrification system and modified approach to bovine matured oocytes vitrification, gave very high yield $(30 \%)$ of blastocyst and one calf was born after transfer of such embryos (see Applications below).

\section{Applications}

1. In vitro production of bovine embryos (from slaughterhouse oocytes or those recovered by OPU - ovum pick up) under various culture conditions and in co-culture with various types of cells (Duszewska et al., 2000).

2. A method of vitrification of bovine oocytes (Papis et al., 2000). International patent.

3. Banking of somatic cells from endangered wild mammalian species (mainly Cervidae). (Karasiewicz et al., 2004).

\section{Research plans}

1. Mammalian cloning using embryonic cells, like mouse ES cells, epithelioid ES-like cells derived from ICMs and embryonic discs of sheep, cattle, pig and rabbit, as well as somatic cells, i.e. foetal and adult fibroblasts of mouse, bank-vole, rabbit, sheep and cow. The studies are mainly directed towards analysis of nucleo-cytoplasmic interactions in preimplantation development of reconstituted embryos.

2. Mouse cloning using nuclear recipients, (different than metaphase II oocytes) such as GV oocytes, pro-MI oocytes, MI oocytes and zygotes in various stages of the cell cycle.

3. Inter-species somatic cloning between the European bison and cattle. The European bison cell nuclei (cultures of cells from three tissues of both sexes have been already established in the laboratory) will be introduced into selectively enucleated bovine zygotes.

4. Generation of chimaeras with the use of somatic cells. The embryonic-somatic chimaeras serve as a model of the influence of early embryonic environment on somatic cells (foetal fibroblasts) in the resulting foetuses and animals.

5. Production of transgenic animals either by pronuclear injection of exogenous DNA (rabbit and cattle) or by transfer of nuclei from in vitro genetically modified embryo-derived cells or fibroblasts (pig). The aim of these studies is to obtain transgenic animals producing human therapeutic proteins - in mammary gland (cattle) or in the urinary bladder (mouse, rabbit) - and whose organs could be used for xenotransplantation in humans (pig).

6 . Establishing the parameters and conditions for successful cryopreservation of mammalian GV oocytes.

\section{References}

BOYLE, M.S., ALLEN, W.R., TISCHNER, M., CZLONKOWSKA, M. (1985). Storage and international transport of horse embryos in liquid nitrogen. Equine Vet. J. Suppl. 3: 36-39.

CZLONKOWSKA, M., BOYLE, M.S., ALLEN, W.R. (1985). Deep freezing of horse embryos. J. Reprod. Fertil. 75: 485-90.

CZLONKOWSKA, M., GUSZKIEWICZ, A., PAPIS, K., KOSSAKOWSKI, M., DZIAK, J., STEZYCKA, E. (1988). Chimerism between the sheep and the goat. Med. Wet., 7: 414-416, in Polish, with English summary.

CZLONKOWSKA. M., EYSYMONT, U., GUSZKIEWICZ, A., KOSSAKOWSKI, M., DZIAK, J. (1991). Birth of lambs after in vitro maturation, fertilization, and coculture with oviductal cells. Mol. Reprod. Dev. 30: 34-38.

DUSZEWSKA, A.M., REKLEWSKI, Z., PIENKOWSKI, M., KARASIEWICZ, J., MODLINSKI, J.A. (2000). Development of bovine embryos on Vero/BRL cell monolayers (mixed co-culture). Theriogenology 54: 1239 - 1247.

GRABAREK, J.B., PLUSA, B., MODLINSKI, J.A., KARASIEWICZ, J. (2004) 
Reconstruction of enucleated germinal vesicle oocytes with blastomere nuclei. Zygote 12: 163-172.

GREDA, P. (2007). Zygotes as recipients in mouse cloning. Ph.D Thesis, Institute of Genetics and Animal Breeding Jastrzebiec. (In Polish).

GREDA, P., KARASIEWICZ, J., MODLINSKI, J.A. (2006). Mouse zygotes as recipients in embryo cloning. Reproduction 132: 741-748.

JASZCZAK, K., CZLONKOWSKA, M., GUSZKIEWICZ, A., PARADA, R. (1991). Cytogenetic analysis of experimental interspecies goat-sheep chimera. $J$. Hered. 82: $244-245$.

JASZCZAK, K., PARADA, R., GUSZKIEWICZ, A. (1999). Cytogenetic study of some tissues and age-related changes in cell proportions in a goat-sheep chimera. Cytogenet. Cell Genet. 84: 55-7.

KARASIEWICZ, J., KRZYWINSKI, A., ZURKOWSKI, M., MODLINSKI, J.A. (2004). Establishing of cell lines from some Cervidaespecies and from European bison (wisent). Reprod. Domestic Anim. 39: 275.

KARASIEWICZ, J., SACHARCZUK, M., WAS, B., GUSZKIEWICZ, A., KOSSAKOWSKI, M., GORNIEWSKA, M., SZABLISTY, MODLINSKI, J.A. (2008). Experimental embryonic-somatic chimaerism in the sheep confirmed by random amplified polymorphic DNA (RAPD) assay. Int. J. Dev. Biol. 52: 315-322.

KARASIEWICZ, J., SZABLISTY, E., GUSZKIEWICZ, A., KOSSAKOWSKI, M., STEFANSKI, G., REED, M., MODLINSKI, J.A. (1996). Development of isolated sheep inner cell masses/embryonic discs in vitro. Roux's Arch. Dev. Biol. 205: 437-442.

MODLINSKI, J.A. (1975). Haploid mouse embryos obtained by microsurgical removal of one pronucleus. J. Embryol. Exp. Morphol. 33: 897-90

MODLINSKI, J.A. (1995). Cloning of mammalian embryos - the use of embryonic stem cells and the effect of some nucleo-cytoplasmic factors on the development of reconstructed embryos. Prace i Mat. Zootech. 4: 1-98, in Polish.
MODLINSKI, J.A., GORNIEWSKA, M., MODLINSKA, M.K., REED, M.A., WAGNER, T.E., KARASIEWICZ, J. (2003). Trophoblastic vesicles as putative carriers of mouse embryonic stem cells. Theriogenology 59: 357.

MODLINSKI, J.A., REED, M.A., WAGNER, T.E., KARASIEWICZ, J. (1996). Embryonic stem cells: developmental capabilities and their possible use in mammalian embryo cloning. Anim. Reprod. Sci. 42: 437-446.

MODLINSKI, J.A., STEFANSKI, G., GORNIEWSKA, M., KORWIN-KOSSAKOWSKI, M., REED, M.A., GUSZKIEWICZ, A., KARASIEWICZ, J. (2004). Trophoblastic vesicles as carriers of embryonic cells for mammalian cloning. J. Anim. Feed Sci., 13: $199-206$.

MOHAMMED, A.A., KARASIEWICZ, J. and MODLINSKI, J.A. (2008). Developmental potential of selectively enucleated immature mouse oocytes upon nuclear transfe. Molec. Reprod. Dev. (in press, doi: 10.1002/mrd.20870).

PAPIS, K., SHIMIZU, M., IZAIKE, Y. (1999). A highly efficient modified vitrification method for Day 3 in vitro produced bovine embryos. Cryo-Letters 20: 203-206.

PAPIS, K., SHIMIZU, M., IZAIKE,Y. (2000) Factors affecting the survivability of bovine oocytes vitrified in droplets. Theriogenology 54: 651-658.

PILISZEK, A., MODLINSKI, J.A., PYSNIAK, K., KARASIEWICZ, J. (2007). Foetal fibroblasts introduced to cleaving mouse embryos contribute to full-term development. Reproduction 133: 207-218.

PIOTROWSKA, K., MODLINSKI, J.A., KORWIN-KOSSAKOWSKI, M., KARASIEWICZ, J. (2000). Effects of preactivation of ooplasts or synchronization of blastomere nuclei in $\mathrm{G} 1$ on preimplantation development of rabbit serial nuclear transfer embryos. Biol. Reprod. 63: 677- 682.

PLUSA, B., GRABAREK, J.B., KARASIEWICZ, J., MODLINSKI, J.A. (2005) Meiotic maternal chromosomes introduced to the late mouse zygote are recruited to later embryonic divisions. Molec. Reprod. Dev. 70: 429-437.

\section{Related, previously published Int. J. Dev. Biol. articles}

See our recent Special Issue Developmental Biology in Poland edited by Kloc, Maleszewski and Tarkowski at: http://www.ijdb.ehu.es/web/contents. php?vol=52\&issue=2-3

See our Special Issue Mammalian Reproduction \& Development in honor of Anne McLaren and edited by Brigid Hogan at: http://www.ijdb.ehu.es/web/contents. php?vol=45\&issue=3

Sclerotome development and morphogenesis: when experimental embryology meets genetics Anne-Hélène Monsoro-Burq

Int. J. Dev. Biol. (2005) 49: 301-308

Mammalian neural tube grafting experiments: an in vitro system for mouse experimental embryology.

D Echevarría, C Vieira and S Martínez

Int. J. Dev. Biol. (2001) 45: 895-902

Experimental embryology in Soviet Russia: the case of Dmitrii P. Filatov (1876-1943).

T A Dettlaff and S G Vassetzky

Int. J. Dev. Biol. (1997) 41: 781-787

Experimental embryology in Japan, 1930-1960. A historical background of developmental biology in Japan.

T S Okada

Int. J. Dev. Biol. (1994) 38: 135-154

A pioneer of experimental mammalian embryology: Jacques Mulnard.

$\mathrm{H}$ Alexandre

Int. J. Dev. Biol. (1992) 36: 25-27

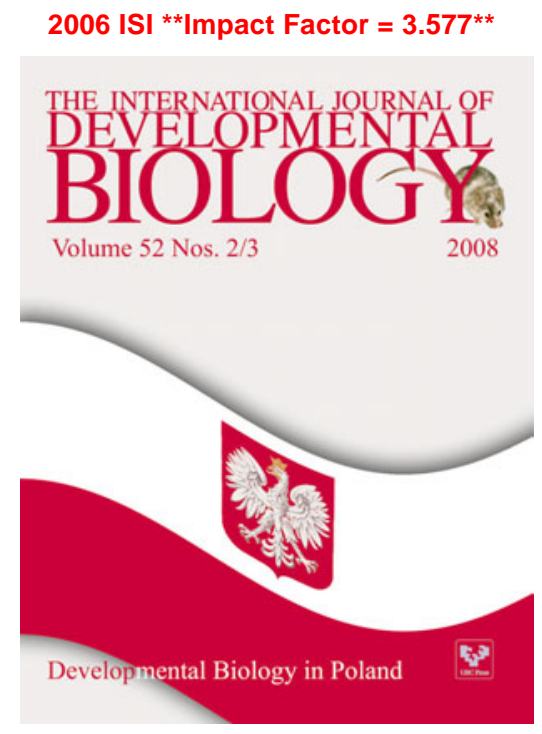

